Original Article

\title{
EFFECT OF COMBINATION OF TWO PLANT EXTRACTS ON DIABETES MELLITUS
}

\author{
JOSE DEEPA ${ }^{1 *}$, N. A. ALEYKUTTY², HARINDRAN JYOTI ${ }^{3}$ \\ ${ }^{1 *}$ Vice Principal, Nirmala College of Pharmacy, Muvattupuzha, Kerala, India, ${ }^{2}$ Principal, Caritas College of Pharmacy, Kottayam, Kerala, \\ India, ${ }^{3}$ Principal and Head of the Research Centre, Department of Pharmaceutical Sciences, Cheruvandoor, Kottayam, Kerala, India \\ Email: deepa.shoby@gmail.com
}

Received: 03 Dec 2017 Revised and Accepted: 05 Mar 2018

\begin{abstract}
Objective: To investigate the anti-diabetic activity of combined ethanolic extracts (1:1mixture) of dry leaves of Syzygium cumini and Psidium guajava belonging to the family Myrtaceae as well as to compare the anti-diabetic activity of these plants by in vitro methods.

Methods: In vitro glucose uptake assay was performed on cultured L6 cell lines (rat myoblast cell line) and estimated the glucose uptake using high sensitivity glucose oxidase kit. In vitro alpha amylase inhibitory assay was performed on porcine alpha amylase and the absorbance was measured at $540 \mathrm{~nm}$ using a microplate reader. Acarbose was used as the standard in both the methods.

Results: At a concentration of $100 \mu \mathrm{g} / \mathrm{ml}$ the percentage glucose uptake by the combined ethanolic extract (1:1 mixture) of Syzygium cumini and Psidium guajava leaves was 43.95 while for acarbose the corresponding value was 51.71 . At $100 \mu \mathrm{g} / \mathrm{ml}$ the percentage of glucose uptake by Syzygium cumini and Psidium guajava was 27.62 and 22.17 respectively. The percentage inhibition of alpha amylase by the combined ethanolic extract (1:1 mixture) of Syzygium cumini and Psidium guajava leaves at a concentration of $1000 \mu \mathrm{g} / \mathrm{ml}$ was 36.51 and it was 29.26 for Syzygium cumini and 23.43 for Psidium guajava. For acarbose the percentage inhibition of alpha amylase was 73.82 at the concentration of $1000 \mu \mathrm{g} / \mathrm{ml}$.

Conclusion: The combined extract of the leaves of the plants selected was found to be more effective than individual plant extracts against diabetes. The percentage glucose uptake of the combined extract was found to be closer to that of the standard drug acarbose. On comparison of two plants Syzygium cumini was found to be more active against diabetes than Psidium guajava. As the 1:1 mixture of the ethanolic extract is found to be more active, the combination of the two plants can be used to formulate drugs for treating diabetes.
\end{abstract}

Keywords: Glucose uptake assay, Alpha amylase inhibitory assay, Syzygium cumini and Psidium guajava

(C) 2018 The Authors. Published by Innovare Academic Sciences Pvt Ltd. This is an open access article under the CC BY license (http://creativecommons.org/licenses/by/4.0/) DOI: http://dx.doi.org/10.22159/ijpps.2018v10i4.24100

\section{INTRODUCTION}

Syzgium cumini (Synonym: Eugenia jambolan Linn.) family Myrtaceae is a very large evergreen tropical tree [fig. 1]. The different parts of this plants have been used for a wide variety of ailments including cough, diabetes, dysentery, inflammation, pharyngitis, dermopathies, constipation, leucorrhoea and ringworm [1-3]. Psidium guajava L. known as Guava is a medicinal plant belonging to the family Myrtaceae [fig. 2]. Traditionally it is used for anorexia, cholera, diarrhoea, digestive problems, dysentery, gastric insufficiency, inflamed mucous membranes, laryngitis, skin problems, sore throat, ulcers, aches, bacterial infections, boils, bowel disorders, bronchitis, cold, colic, convulsions, cough, dyspepsia, oedema and epilepsy. Psidium guajava leaf extract is a potential reducing agent with biomedical applications $[4,5]$.

Diabetes mellitus (DM) which is one of the public health issues is a metabolic disorder characterized by the presence of chronic hyperglycaemia accompanied by an impairment of carbohydrate, lipid and protein metabolism that can lead to premature death. According to International Diabetes Federation report by 2030 almost around 552 million will have DM. The 1997 American diabetic association's recommendations for diagnosis of DM focus on fasting plasma glucose (FPG) while WHO focuses on oral glucose tolerance test [6-8]. In 2014, 422 million adults were living with diabetes compared to 108 million in 1980 across the world. Diabetes caused 1.5 million deaths in 2012. An additional 2.2 million deaths were caused by higher than optimal blood glucose by increasing the risks of cardiovascular and other diseases [9].

Insulin dependent diabetes mellitus (TYPE 1 DM) known as "juvenile diabetes" occurs due to failure of pancreas to secrete enough insulin and is characterized by beta cell destruction caused by an autoimmune process; leading to absolute insulin deficiency. Type 1
DM is characterized by the presence of anti-glutamic acid decarboxylase or insulin antibodies which identify the autoimmune processes that lead to beta cell destruction. Non-insulin dependent diabetes mellitus (Type 11 DM) known as adult onset diabetes begins with insulin resistance in which cells fail to respond to insulin properly. Lack of exercise and obesity may lead to this condition. Type 11 DM comprises $80 \%$ to $90 \%$ of all cases of DM. Diabetes which is triggered by pregnancy is called gestational diabetes as pregnancy may lead to insulin resistance. Around $10 \%$ of women with gestational diabetes may develop type II diabetes later [10]. Diabetes due to genetic defects of beta cell function or with defects of insulin action, diseases of the exocrine pancreas such as pancreatitis or cystic fibrosis, dysfunction associated with other endocrinopathies (e. g. acromegaly); and with pancreatic dysfunction caused by drugs, chemicals or infections are grouped together as monogenic or other specific type diabetes [11].

According to world ethno botanical information reports almost 800 plants possess anti diabetic potential. Hypoglycaemic agents from natural products are gaining more importance due to their lower side effects. The use of phytochemicals may delay the development of diabetic complications and may regulate the metabolic abnormalities by different mechanisms. Several plants can be used as potential sources of new drugs to complement existing oral hypoglycaemic agents [12-14].

The aim of the present study was to compare the anti-diabetic activity of ethanolic extract of Syzygium cumini and Psidium guajava leaves and to investigate the anti-diabetic activity of the combined extract of both the plants. This study was designed with an objective to perform the in vitro glucose uptake assay on cultured $L 6$ cell lines and alpha amylase inhibitory assay of the plants under study individually and as a combination of ethanolic leaf extracts of both Syzygium cumini and Psidium guajava. 


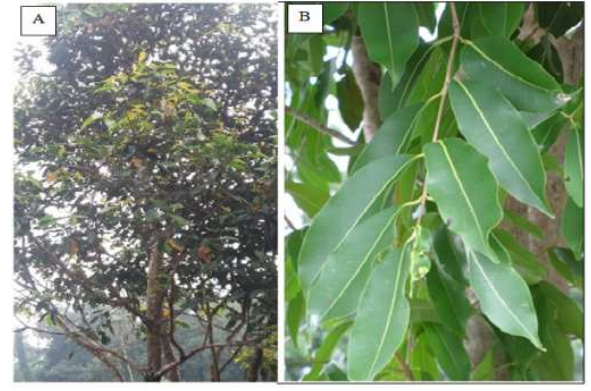

Fig. 1: A. Syzygium cumini tree, B. Syzygium cumini leaves

Source of fig.: Photographs of the tree and leaves were taken from Idukki District of Kerala.

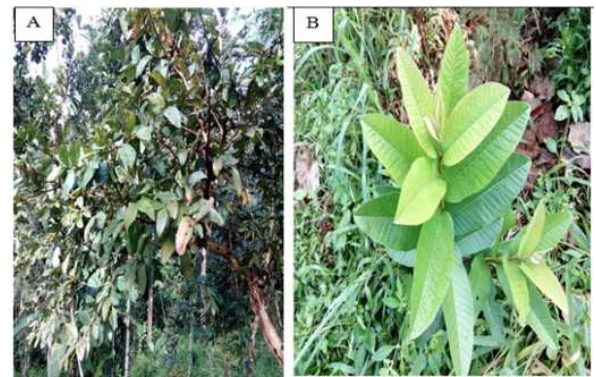

Fig. 2: A. Psidium guajava tree, B. Psidium guajava leaves

Source of fig.: Photographs of the tree and leaves were taken from Idukki District of Kerala.

\section{MATERIALS AND METHODS}

\section{Chemicals and reagents}

L6 cell line (rat myoblast cell line) was purchased from NCCS Pune and Dulbecco's modified eagle's media (DMEM) from Sigma Aldrich, USA. All other chemicals were procured either from Sigma, Ranbaxy fine Chemicals, New Delhi, Hi Media Mumbai or NICE chemicals Ltd, Cochin, Kerala, India.

\section{Collection and authentication of plant material}

The leaves of both plants were collected from the hilly regions of Idukki District, which is a densely forested mountainous region in the south Indian state of Kerala and were authenticated by Dr. Sr. Tessy Joseph, Professor, Department of Botany, Nirmala College, Muvattupuzha. Voucher specimen was deposited in the herbarium of Nirmala college, Muvattupuzha, Kerala, India with a Voucher no: NCBD 3812.

\section{Preparation of extracts}

The mature leaves of both Psidium guajava and Syzygium cumini were shade dried separately powdered in grinder to get coarse powder for extraction. $250 \mathrm{~g}$ of the Syzygium cumini leaf powder was extracted in ethanol (2.5 l) in a Soxhlet apparatus and concentrated to yield the crude ethanol extract of Syzygium cumini SC EL. Similarly $250 \mathrm{~g}$ of the crude powder of Psidium guajava leaf was extracted in ethanol (2.5 l) and concentrated to yield the crude ethanol extract of Psidium guajava PG EL. The extracts were concentrated using vacuum evaporator.

\section{In vitro glucose uptake assay on cultured $L 6$ cell lines}

The $L 6$ cell line (rat myoblast cell) was maintained in Dulbecco's modified eagles media supplemented with $10 \%$ foetal bovine serum (FBS). The cells were grown to confluency at $37^{\circ} \mathrm{C}$ in $5 \% \mathrm{CO}_{2}$ in a humidified atmosphere in a $\mathrm{CO}_{2}$ incubator (NBS, Eppendorf, Germany). The cells were trypsinized with $500 \mu \mathrm{l}$ of $0.025 \%$ trypsin in phosphate buffered saline (PBS) $/ 0.5 \mathrm{mmol}$ ethylene diamine tetra acetic acid (EDTA) solution (In vitrogen) for $2 \mathrm{~min}$ and passaged to T flasks in complete aseptic conditions. The cells were subcultured to a 24 well plate. The cells were kept in DMEM without glucose for $24 \mathrm{~h}$ after attaining $80 \%$ confluency. To the grown cells added the extracts at a final concentration of $25 \mu \mathrm{g}, 50 \mu \mathrm{g}$ and $100 \mu \mathrm{g}$ from a stock of $1 \mathrm{mg} / \mathrm{ml}$ and incubated in DMEM containing $300 \mathrm{mmol}$ glucose for $24 \mathrm{~h}$. An untreated control with high glucose was also maintained. The cells were isolated after incubation by spinning at $6000 \mathrm{rpm}$ for $10 \mathrm{~min}$. The supernatant was discarded and added 200 $\mu \mathrm{l}$ of cell lysis buffer (1MTrisHcl, 0.25M EDTA, 2M Nacl, 0.5\% Triton). The mixture was incubated for $30 \mathrm{~min}$ at $4{ }^{\circ} \mathrm{C}$ and estimated the glucose uptake using high sensitivity glucose oxidase kit. All experiments were repeated in triplicates and mean average was used for calculations [15].

$\%$ Glucose uptake $=$ OD of test - OD of Control $\div$ OD of test $\times 100$

\section{In vitro alpha amylase inhibitory assay}

Different concentrations of samples $(125 \mu \mathrm{g} / \mathrm{ml}-1000 \mu \mathrm{g} / \mathrm{ml})$ were prepared from a stock concentration of $10 \mathrm{mg} / \mathrm{ml}$ and made up to $1000 \mu \mathrm{l}$ using $25 \mathrm{mmol}$ phosphate buffer $\mathrm{pH} 6.9$, containing $25 \mu \mathrm{l}$ of porcine $\alpha$ amylase at a concentration of $0.5 \mathrm{mg} / \mathrm{ml}$. The mixtures were incubated at $25{ }^{\circ} \mathrm{C}$ for $10 \mathrm{~min}$. After pre incubation, $25 \mu \mathrm{l}$ of $0.5 \%$ starch solution in $25 \mathrm{mmol}$ phosphate buffer $\mathrm{pH} 6.9$ was added to the mixtures. The reaction mixtures were then incubated at $25^{\circ} \mathrm{C}$ for $10 \mathrm{~min}$. The reaction was stopped with $50 \mu \mathrm{l}$ of $96 \mathrm{mmol} \mathrm{3,5-}$ dinitro salicylic acid colour reagent. The micro plate was then incubated in a boiling water bath for 5 min and cooled to room temperature. Absorbance was measured at $540 \mathrm{~nm}$ using a microplate reader (Erba, Lisascan) [16].

\section{CALCULATION}

$$
\% \text { inhibition }=\frac{\text { control-test }}{\text { control }} \times 100
$$

Table 1: Effect of different concentrations of acarbose and the plant extracts on glucose uptake by the $L 6$ cell lines

\begin{tabular}{llllll}
\hline S. No. & Sample & Concentration & Absorbance & Percentage glucose uptake $(\boldsymbol{\mu g} / \mathbf{m l})$ & Bias \\
\hline 1 & Control & - & $0.1702 \pm 0.96$ & - \\
2 & Acarbose & 25 & $0.2900 \pm 1.02$ & 41.31 \\
& (Standard) & 50 & $0.3189 \pm 1.34$ & 46.63 & 0.0893 \\
& & 100 & $0.3525 \pm 1.22$ & 51.71 & 0.1041 \\
3 & Ethanolic extract of & 25 & $0.2007 \pm 0.98$ & 15.23 & 0.1174 \\
& Syzygium cumini & 50 & $0.2148 \pm 1.65$ & 20.79 & 0.1064 \\
& (SC EL) & 100 & $0.2351 \pm 0.94$ & 27.62 & 0.1154 \\
4 & Ethanolic extract of & 25 & $0.1836 \pm 1.79$ & 7.3 \\
& Psidium guajava & 50 & $0.2035 \pm 0.98$ & 16.4 & 0.1339 \\
& (PG EL) & 100 & $0.2186 \pm 0.86$ & 22.17 & 0.0627 \\
& 1:1 mixture of & 25 & $0.2273 \pm 1.54$ & 25.15 & 0.0535 \\
& SC EL and PG EL & 50 & $0.2654 \pm 1.12$ & 35.87 & 0.0489 \\
\hline
\end{tabular}




\section{RESULTS AND DISCUSSION}

The 1:1 mixture of ethanolic extract of Psidium guajava and Syzygium cumini leaves was found to possess good glucose uptake activity than either of the individual extracts. The percentage of glucose uptake by ethanolic extract of the leaves of Psidium guajava, Syzygium cumini, 1:1 mixture of both and acarbose, the standard drug are tabulated in table 1 . The result showed that the combined extract has good activity comparable with that of acarbose. Results are expressed as mean $\pm S D(n=3)$. The glucose uptake assay on $L 6$ rat myoblast cells was performed at three concentrations 25, 50 and 100 $\mu \mathrm{g} / \mathrm{ml}$. The results revealed that the combined ethanolic extract (1:1 mixture) of Psidium guajava and Syzygium cumini at $100 \mu \mathrm{g} / \mathrm{ml}$ increased the glucose uptake by $43.95 \%$ compared to control. The percentage increase in glucose uptake by acarbose the standard drug at $100 \mu \mathrm{g} / \mathrm{ml}$ was 51.71 . At $100 \mu \mathrm{g} / \mathrm{ml}$ the percentage increase in glucose uptake by Syzygium cumini and Psidium guajava was 27.62 and 22.17 respectively on comparison with control. All the extracts showed a dose dependant increase in glucose uptake by $L 6$ rat myoblast cells.

Table 1: The percentage increase of glucose uptake of standard drug acarbose, ethanolic extract of Syzygium cumini (SC EL), Psidium guajava (PG EL) and the 1:1mixture of ethanolic extracts of Syzygium cumini and Psidium guajava (SC EL+PG EL) at $25 \mu \mathrm{g} / \mathrm{ml}, 50 \mu \mathrm{g} / \mathrm{ml}$ and $100 \mu \mathrm{g} / \mathrm{ml}$ with respect to control. Results are expressed as mean $\pm S D(n=3)$ and statistical significance was evaluated by oneway analysis of variance (ANOVA). The percentage of glucose uptake by SC EL, PG EL and the 1:1 mixture of SC EL+PG EL was compared with standard acarbose and the $P$ values are $0.827,0.856$ and 0.359 respectively. The mixture SCEL+PG EL has least difference from the standard acarbose when compared with others. The bias of absorbance values calculated with respect to the standard drug acarbose is least for 1:1 mixture SC EL+PG EL when compared to the other two test groups.

The In vitro $\alpha$-amylase inhibitory studies demonstrated that the combined ethanolic extract (1:1 mixture) of Psidium guajava and Syzygium cumini has more inhibitory activity on $\alpha$-amylase than individual ethanolic extracts of Psidium guajava and Syzygium cumini. The extracts were tested and compared with the standard drug acarbose for $\alpha$-amylase inhibitory activity at four concentrations $125,250,500$ and $1000 \mu \mathrm{g} / \mathrm{ml}$. The percentage inhibition of $\alpha$-amylase activity by ethanolic extracts of the leaves of Psidium guajava, Syzygium cumini, 1:1 mixture of both and acarbose are tabulated in table 2. Results are expressed as mean $\pm S D(n=3)$. All the extracts showed a dose dependant increase in the inhibitory activity. At a concentration of $1000 \mu \mathrm{g} / \mathrm{ml}$ the combined ethanolic extract (1:1 mixture) of Psidium guajava and Syzygium cumini showed an inhibition of $36.51 \%$ while it was $29.26 \%$ for Syzygium cumini and $23.43 \%$ for Psidium guajava. For standard drug acarbose the percentage inhibition of alpha amylase at $1000 \mu \mathrm{g} / \mathrm{ml}$ was 73.82 .

Table 2: Alpha amylase inhibitory activity of different concentrations of acarbose and the plant extracts on porcine alpha amylase

\begin{tabular}{|c|c|c|c|c|c|}
\hline S. No. & Sample & Concentration $(\mu \mathrm{g} / \mathrm{ml})$ & Absorbance at $540 \mathrm{~nm}$ & Percentage of inhibition & Bias \\
\hline & Acarbose & 125 & $0.0543 \pm 0.86$ & 55.85 & \\
\hline \multirow[t]{4}{*}{1} & (Standard) & 250 & $0.0539 \pm 0.57$ & 58.61 & \\
\hline & & 500 & $0.0492 \pm 0.64$ & 60.00 & \\
\hline & & 1000 & $0.0322 \pm 0.75$ & 73.82 & \\
\hline & & Control & $0.1230 \pm 0.45$ & - & \\
\hline \multirow[t]{5}{*}{2} & Ethanolic extract of & 125 & $0.2113 \pm 0.67$ & 12.54 & 0.1570 \\
\hline & Syzygium cumini & 250 & $0.1941 \pm 0.34$ & 19.66 & 0.1402 \\
\hline & (SC EL) & 500 & $0.1805 \pm 0.53$ & 25.29 & 0.1313 \\
\hline & & 1000 & $0.1709 \pm 0.66$ & 29.26 & 0.1387 \\
\hline & & Control & $0.2416 \pm 0.47$ & - & 0.1186 \\
\hline \multirow[t]{5}{*}{3} & Ethanolic extract of & 125 & $0.2132 \pm 0.66$ & 11.75 & 0.1589 \\
\hline & Psidium guajava & 250 & $0.2016 \pm 0.57$ & 16.56 & 0.1477 \\
\hline & $(P G E L)$ & 500 & $0.1977 \pm 0.76$ & 18.17 & 0.1485 \\
\hline & & 1000 & $0.1850 \pm 0.87$ & 23.43 & 0.1528 \\
\hline & & Control & $0.2416 \pm 0.42$ & - & 0.1186 \\
\hline \multirow[t]{5}{*}{4} & 1:1 mixture of & 125 & $0.1905 \pm 0.43$ & 21.15 & 0.1362 \\
\hline & SC EL and PG EL & 250 & $0.1767 \pm 0.42$ & 26.86 & 0.1228 \\
\hline & & 500 & $0.1739 \pm 0.75$ & 28.02 & 0.1247 \\
\hline & & 1000 & $0.1534 \pm 0.68$ & 36.51 & 0.1212 \\
\hline & & Control & $0.2416 \pm 0.74$ & - & 0.1186 \\
\hline
\end{tabular}

Table 2: Alpha amylase inhibitory activity of standard drug acarbose, ethanolic extract of Syzygium cumini (SC EL), Psidium guajava (PG EL) and the 1:1mixture of ethanolic extracts of Syzygium cumini and Psidium guajava (SC EL+PG EL) at $125 \mu \mathrm{g} / \mathrm{ml}, 250 \mu \mathrm{g} / \mathrm{ml}, 500 \mu \mathrm{g} / \mathrm{ml}$ and $1000 \mu \mathrm{g} / \mathrm{ml}$ with respect to control. Results are expressed as mean $\pm S D(n=3)$ and statistical significance was evaluated by oneway analysis of variance (ANOVA). The percentage inhibition of alpha amylase by SC EL, PG EL and SCEL+PG EL was compared with standard acarbose and the $P$ values are $0.937,0.968$ and 0.908 respectively. The mixture SCEL+PG EL has least difference from the standard acarbose, when compared with others. The bias of absorbance values calculated with respect to the standard drug acarbose is least for 1:1 mixture SC EL+PG EL when compared to the other two test groups.

Insulin resistance, which is the reduced response of target tissues such as the skeletal muscle, liver, and adipocytes to insulin, plays a major role in the pathogenesis of Type II Diabetes. Skeletal muscle is the predominant site of insulin-mediated glucose uptake in the postprandial state. Normal glucose homeostasis depends on a wellbalanced interaction between tissue (muscle, liver and fat) sensitivity to insulin and insulin secretion [17]. The present study showed that the ability of the combined ethanolic extract of Syzygium cumini and Psidium guajava to increase the percentage glucose uptake is comparable to that of the standard drug acarbose showing its ability to reduce post prandial blood sugar level.

Type II Diabetes mellitus can be treated by reducing post prandial hyperglycaemia. The intestinal digestive enzyme alpha amylase is a carbohydrate hydrolyzing enzyme. Alpha amylase inhibitors prevent break down of polysaccharide in to mono and disaccharide. Thus alpha amylase inhibitors can prevent the postprandial hyperglycaemia by preventing glucose release from starch and delaying carbohydrate metabolism [18]. This research demonstrated the better anti diabetic potential of the 1:1 mixture of ethanolic extract of Syzygium cumini and Psidium guajava leaves by its ability to inhibit alpha amylase more effectively than either of the individual plant extracts of Syzygium cumini and Psidium guajava leaves.

The results of the glucose uptake assay and alpha amylase inhibitory assay demonstrated that even though the individual ethanolic plant extracts of Syzygium cumini and Psidium guajava could increase the glucose uptake and inhibit the alpha amylase activity, the combined ethanolic extracts of both the plants increased the glucose uptake 
and inhibited the alpha amylase more efficiently than individual plants. So the combined ethanolic extract (1:1 mixture) of Psidium guajava and Syzygium cumini can act as a better anti diabetic agent. Plants containing various phytochemicals exhibit additive and synergistic interaction in exerting anti diabetic properties which is a beneficial effect to formulate more potent anti-diabetic drugs in combination [19].

\section{CONCLUSION}

In the present study the ethanolic extract of leaves of Psidium guajava, Syzygium cumini and 1:1 mixture of ethanolic extract of both Psidium guajava and Syzygium cumini leaves increased the glucose uptake by L6 rat myoblast cells and exhibited alpha amylase inhibition properties. This indicates the ability of the plants under study to act as anti-diabetic agents. Among the three extracts studied the combined extract of Psidium guajava and Syzygium cumini was found to be more active than either of the plants alone. Further studies are recommended to find the mechanism behind this synergistic or additive effect. This study also suggests that the active compounds isolated from these plants can be used as lead compound for designing potent anti-diabetic drugs. Based on the future investigations the plants can be utilised as the components of a polyherbal formulation for treating diabetes.

\section{ACKNOWLEDGEMENT}

The authors are thankful to Biogenix Research Laboratory, Trivandrum, Kerala for helping in performing In vitro studies and also express a sincere gratitude to Sr. Ann Maria, Prasanth B and Somin Joseph of Nirmala College of Pharmacy.

\section{AUTHOR CONTRIBUTIONS}

Jose Deepa conducted the experiment and prepared the manuscript. Dr. N A Aleykutty designed the experiment and Dr. Harindran Jyoti contributed in experimental part of the work.

\section{CONFLICT OF INTERESTS}

The authors confirm that this article content has no conflict of interest.

\section{REFERENCES}

1. Orwa C, Mutua A, Kindt R, Jamnadass R, Simons A. Syzygiumcuminii (L.) skeels Myrtaceae. Agroforestry database: a tree species Reference and Selection Guide; 2009;40:1-5.

2. Ayyanar M, Subash-Babu P. Syzygiumcumini (L.) skeels: a review of its phytochemical constituents and traditional uses. Asian Pac J Trop Biomed 2012;2:240-6.

3. Pradhan M. Phytochemistry, pharmacology and novel delivery applications of Syzygiumcumini. Int J Pharm Pharm Res 2016;7:659-75.
4. Shirur Dakappa Shruthi, Adhikari Roshan, Sanjay Sharma. A review on the medicinal plant Psidium Guajava Linn. (Myrtaceae). J Drug Delivery Ther 2013;3:162-8.

5. Sharmila C, Ranjith Kumar R, Chandar Shekar B. Psidium guajava: a novel plant in the synthesis of silver nanoparticles for biomedical applications. Asian J Pharm Clin Res 2018;11:341-5.

6. Thenmozhi P, Vijayalakshmi M. Knowledge on hypoglycemia among patients with diabetes mellitus. Asian J Pharm Clin Res 2018;11:236-9.

7. Swathiputta, Vijay C Ahedalawada. Dose dependent effect on hypoglycemic and antihyperglycemic activities of chloroform extract of Physalis minima in streptozotocin induced diabetic rats. Int J Curr Pharm Res 2014;6:61-5.

8. Olokoba AB, Obateru OA, Olokoba LB. Type 2 diabetes mellitus: a review of current trends. Oman Med J 2012;27:269-73.

9. World Health Organization. Global Report on Diabetes 2016;978:88.

10. Alberti KG, Zimmet PZ. WHO. Definition, diagnosis and classification of diabetes mellitus and its complications. part 1: diagnosis and classification of diabetes mellitus provisional report of a WHO consultation. Diabet Med 1998;15:539-53.

11. Gaby AD. Diabetes Mellitus. Nutr Med 2011;3:1081-105.

12. Patience 00, Estella UO, Philip FU. The search for new hypoglycemic agents from plants. Afr J Pharm Pharmacol 2014;8:292-303.

13. Gaikwad SB, Krishna Mohan G, Sandhya Rani M. Phytochemicals for diabetes management. Pharmaceutical Crops 2014;5(Suppl 1:M2):11-28.

14. Rosalie IO, Ekype EL. Antidiabetic potentials of common herbal plants and plant products: A glance. Int J Herb Med 2016;4:90-7.

15. Yap A, Nishiumi S, Yoshida KI, Ashida H. Rat L6 myotubes as an in vitro model system to study GLUT4-dependent glucose uptake stimulated by inositol derivatives. Cytotechnology 2007;55:103-8.

16. Wickramaratne MN, Punchihewa JC, Wickramaratne DBM. In vitro alpha amylase inhibitory activity of the leaf extracts of Adenanthera pavonina. BMC Complement Altern Med 2016;16:466-75.

17. DeFronzo RA, Tripathy D. Skeletal muscle insulin resistance is the primary defect in type 2 diabetes. Diabetes Care 2009;32 Suppl 2:157-63.

18. Safamansouri H, Nikan M, Amin G, Sarkhail P, Gohari AR, Kurepaz-Mahmoodabadi M, et al. $\alpha$-Amylase inhibitory activity of some traditionally used medicinal species of Labiatae. J Diabetes Metab Disord 2014;13:114-23.

19. Gupta RC, Chang D, Nammi S, Bensoussan A, Bilinski K, Roufogalis BD. Interactions between antidiabetic drugs and herbs: an overview of mechanisms of action and clinical implications. Diabetol Metab Syndr 2017;9:59-65. 